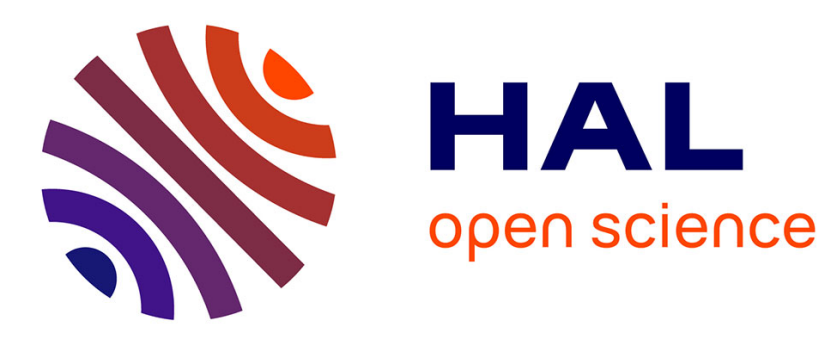

\title{
Seismically reactivated Hattian slide in Kashmir, Northern Pakistan
}

\author{
Jean F. Schneider
}

\section{To cite this version:}

Jean F. Schneider. Seismically reactivated Hattian slide in Kashmir, Northern Pakistan. Journal of Seismology, 2008, 13 (3), pp.387-398. 10.1007/s10950-008-9103-5 . hal-00478432

\section{HAL Id: hal-00478432 \\ https://hal.science/hal-00478432}

Submitted on 30 Apr 2010

HAL is a multi-disciplinary open access archive for the deposit and dissemination of scientific research documents, whether they are published or not. The documents may come from teaching and research institutions in France or abroad, or from public or private research centers.
L'archive ouverte pluridisciplinaire HAL, est destinée au dépôt et à la diffusion de documents scientifiques de niveau recherche, publiés ou non, émanant des établissements d'enseignement et de recherche français ou étrangers, des laboratoires publics ou privés. 


\title{
Seismically reactivated Hattian slide in Kashmir, Northern Pakistan
}

\author{
Jean F. Schneider
}

Received: 20 March 2008 / Accepted: 3 April 2008 / Published online: 14 May 2008

(C) Springer Science + Business Media B.V. 2008

\begin{abstract}
The Pakistan 2005 earthquake, of magnitude 7.6, caused severe damage on landscape and infrastructure, in addition to numerous casualties. The event reactivated Hattian Slide, creating a rock avalanche in a location where earlier mass movements had happened already, as indicated by satellite imagery and ground investigation. The slide originated on Dana Hill, in the upper catchment area of Hattian on Karli Stream, a tributary of Jhelum River, Pakistan, and buried the hamlet Dandbeh and several farms nearby. A natural dam accumulated, impounding two lakes, the larger one threatening parts of downstream Hattian Village with flooding. An access road and artificial spillways needed to be constructed in very short time to minimize the flooding risk. As shown by this example, when pointing out the risk of large-scale damage to population and infrastructure by way of hazard indication maps of seismically active regions, and preparing for alleviation of that risk, it is advisable to consider the complete Holocene history of the slopes involved.
\end{abstract}

J. F. Schneider $(\bowtie)$

Institute of Applied Geology, IAG-BOKU, University of Natural Resources and Applied Life Sciences, Vienna,

P. Jordan - Street 70,

A 1190 Vienna, Austria

e-mail: jean.schneider@boku.ac.at
Keywords Mass movements · Landslides · Seismic triggering $\cdot$ Kashmir earthquake . Landslide dam $\cdot$ Reservoir impounding

\section{Introduction}

On October 8, 2005, a devastating earthquake of magnitude 7.6 occurred, with its epicentre at $34.467^{\circ} \mathrm{N} /$ $73.577^{\circ} \mathrm{E}$ and a focal depth of $26 \mathrm{~km}$ (Fig. 1). In addition to approximately 80,000 fatalities (figures differ between authors, see e. g. Mona Lisa et al. 2006), the event caused severe damage to infrastructure and to the landscape. The earthquake resulted from subduction of the Indian Plate beneath the Eurasian Plate, and the fault plane solutions indicated that the earthquake was due to thrusting (Harvard 2005; USGS 2005; GSP 2005; EMSC 2005). A large number of aftershocks occurred along the Main Boundary Thrust Zone (MBT), striking NW-SE in the relevant section. Epicentres of the aftershocks clustered in the NW part of the continental convergent zone (Fig. 1).

The cities of Muzaffarabad, Balakot and Bagh, lying in the vicinity of the Jhelum thrust fault, were extensively damaged. The author observed the largest shaking intensities in the Khagan, Neelum and Jhelum Valleys, where thousands of landslides, rockslides, rock falls and debris flows were triggered, and rivers were dammed back by some of the larger mass 


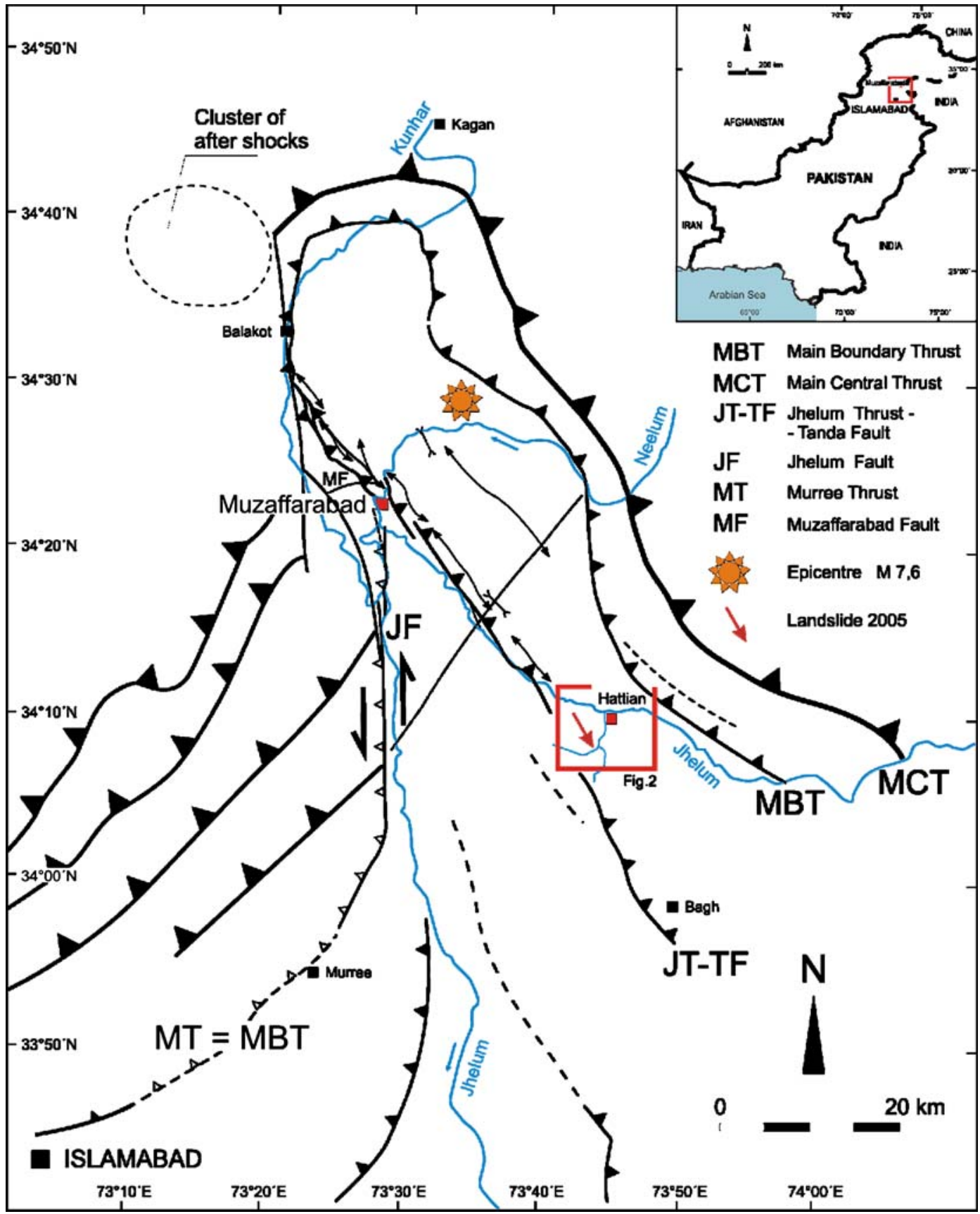

Fig. 1 Seismotectonical sketch map of the Hazara Kashmir Syntaxis. The Hattian Landslide is marked with a red arrow in the right centre of the map. The orange star north of it marks the epicentre of the 8-10-2005 earthquake; the main cluster of aftershocks situated NNW of it. The investigation area shown in Fig. 2 is marked here in red and located near the SE-end of the visible Tanda Fault (compiled from different sources, see text)

Crone 2006; JSCE 2006). The mass movements originated from shattered and steep rock faces and in glacial or fluvial sediments and scree deposits. Substantial erosion associated with rivers of high discharge had resulted in the formation of many over- 
steepened and undercut slopes that were prone to failure (Owen et al. 2006; Aydan 2006).

In many places the shattered rocks that remained in situ on the valley slopes are now in critical equilibrium, exhibiting little cohesion and low friction angles. Intense precipitation, and the consequent rise in pore water pressure, could lead to creeping or even to spontaneous failure of slopes. Several mass movements occurred in the aftermath of the earthquake, and it is likely that many more will follow, especially during the monsoon season, which occurs between July and September.

\section{The Hattian landslide}

In the Jhelum Valley South of Hattian, a large composite landslide was reactivated by the earthquake, forming a huge rock avalanche, called Hattian Slide (but also referred to as Chikar Slide, Dana Slide or Dandbeh Slide). It is an asymmetric wedge slide that originated on Dana Hill $\left(34^{\circ} 09^{\prime} \mathrm{N} / 73^{\circ} 43^{\prime} \mathrm{E}\right.$, altitude 2,080 m) and moved approximately eastwards, creating a natural dam on the valley bottom blocking the waterways of the Karli and Tung tributaries of the Jhelum River, and burying Dandbeh hamlet on the way (Figs. 2 and 3). The reported death toll varies greatly (estimated to be a few hundred by the author and 1,000 by Dunning et al. 2007). Satellite images and ground checks show that several local farms were affected, but no true village is visible on the scenes taken before the event. The remaining farm houses most endangered by further mass movements have subsequently been evacuated. The debris dam (Fig. 4) created by the landslide has formed two lakes. The larger one, called Karli Lake, has resulted in a flooding hazard threatening parts of Hattian further downstream, due to a possible overflow with backward erosion or due to possible flood waves created by, in fact likely, mass movements into the growing lake.

The eastern flank of Dana Hill exhibits a morphology that suggests that it has suffered earlier large mass movements. The author suggests that at least
Fig. 2 Hattian Landslide sketch map. The information shown is interpreted from Kausar et al. (2006) and our own investigations. The perimeter of the "historic" landslide discussed below coincides roughly with landslide 2005

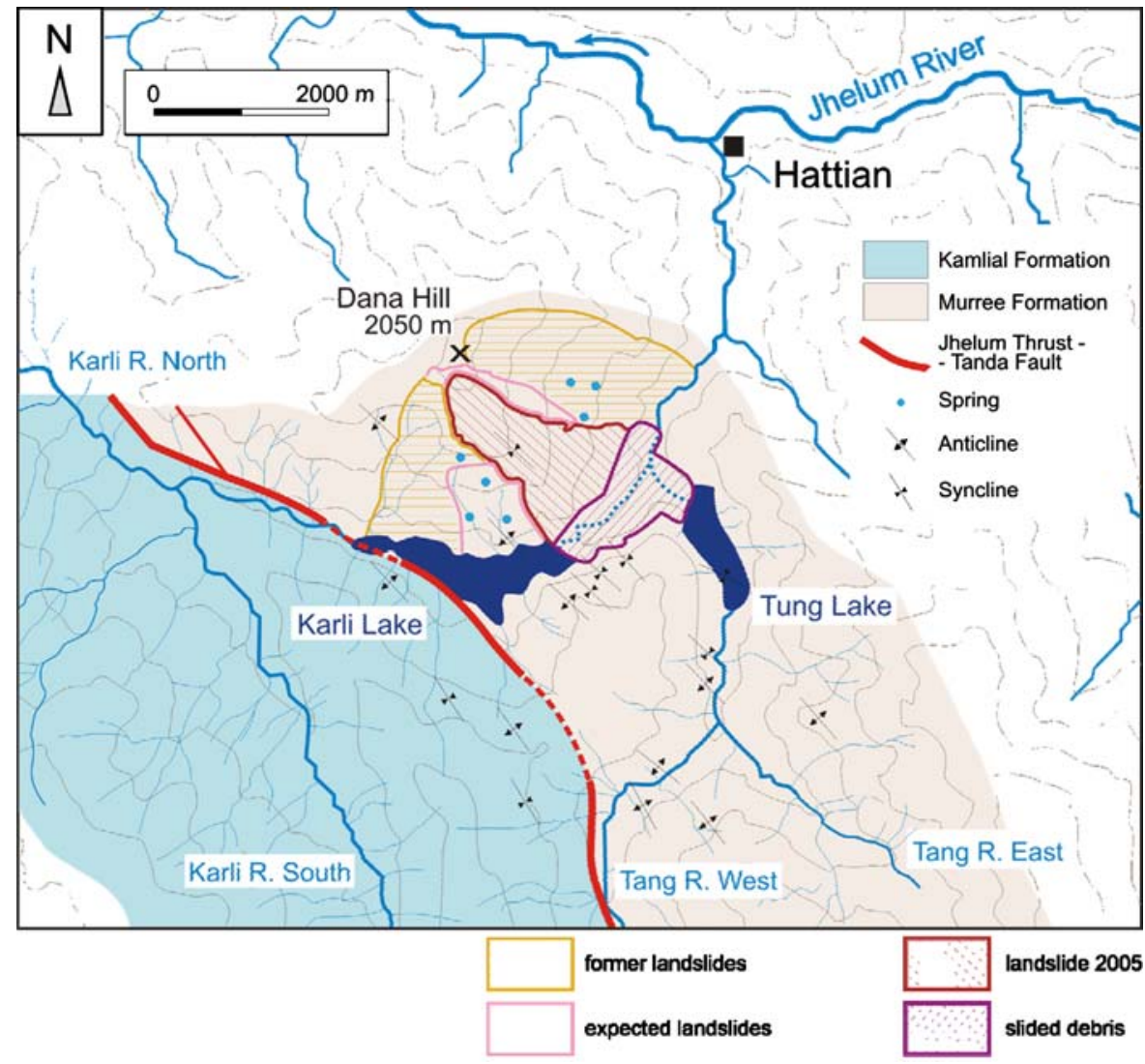


Fig. 3 View from top of the natural dam (1446 $\mathrm{m}$ a.s.1.) westwards towards slide scar on Dana Hill. The asymmetric, ESE dipping syncline can be recognized as well as the large central debris mass that remained in the lower half of the slide. The author postulates an older consolidated slide mass, only partly affected by the actual slide, and partly buried below this actual debris. Secondary slumps appear at the front of this mass and a secondary steeply inclined slide is clearly visible at the right (northern) edge of the photograph of early December 2005

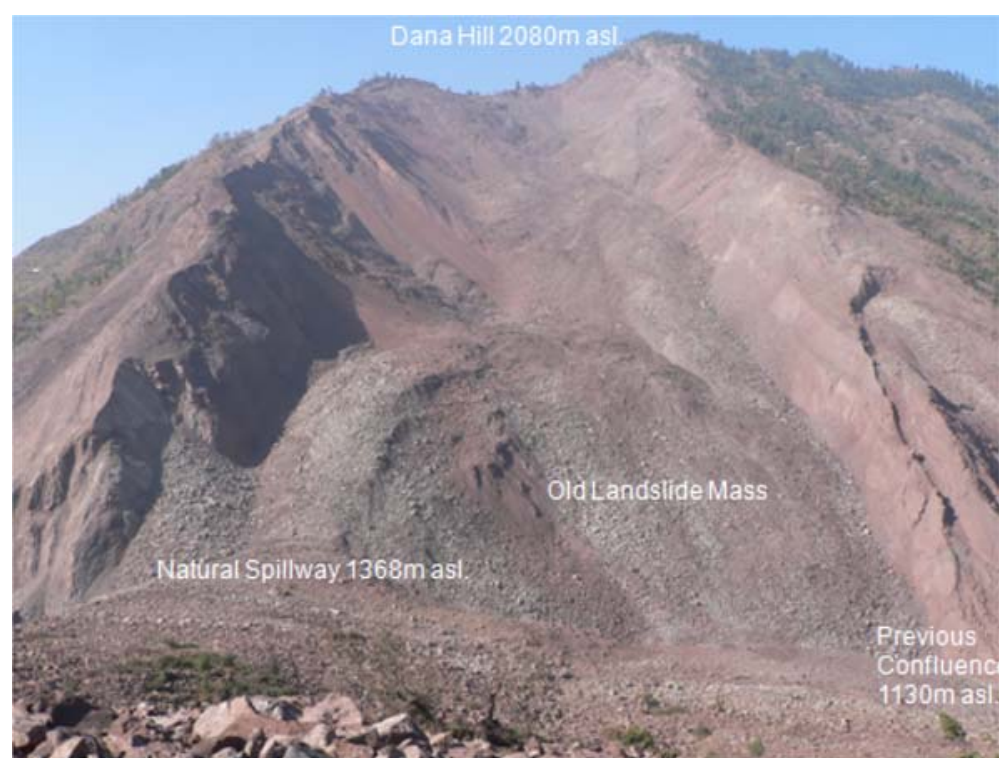

two large rock slides from top of Dana Hill occurred during the Holocene. The first one possibly originated from deglaciation (loss of support by a former glacial ice wedge in the valley) some several thousand years ago and/or was triggered by past earthquakes. It is supposed to having left two large scars on the mountain, a clear one facing east, another one facing south (see Fig. 2). The other postulated former slide was a younger, probably historic landslide at the same location as the actual landslide.

Several authors (e.g. Tapponnier et al. 2006) report from the region a seismic gap along the MBT, in

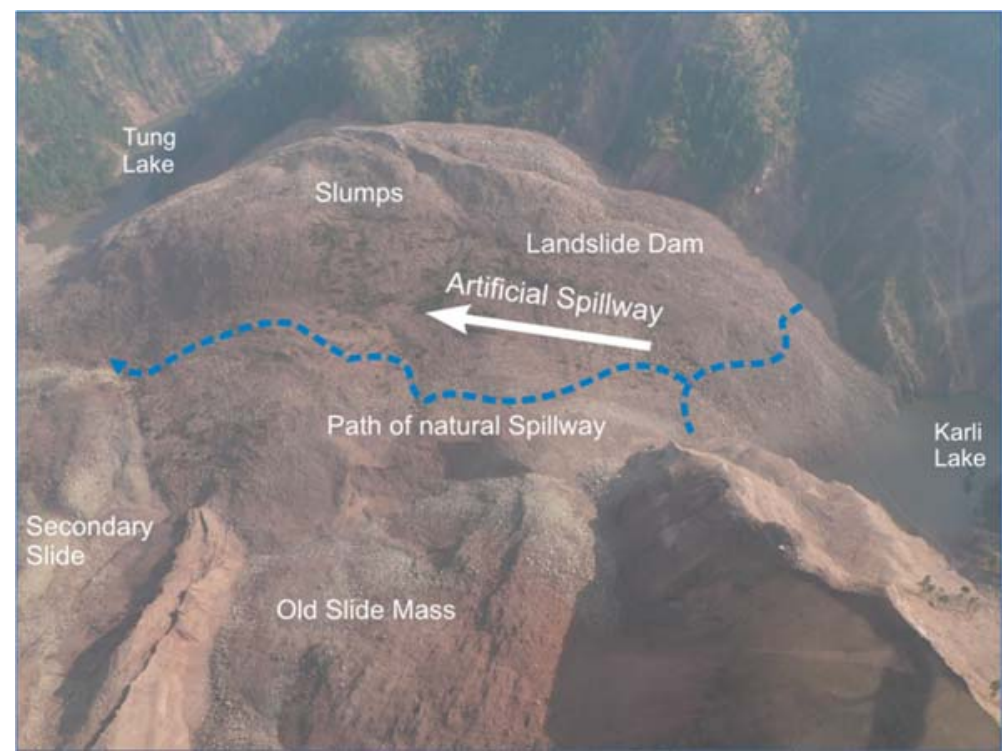

Fig. 4 Helicopter view from above slide eastwards towards the natural dam formed by the landslide debris. At least three ridges can be distinguished, confirming the locally reported three surges. The above mentioned secondary slumps and slides can be seen in the foreground. Slumps have also slid northwards from the crest of the new debris dam. Vegetation on the contact between debris mass and opposite slope is intact and a distal trough was left open. This oblique photograph of early
December 2005 also shows the growing Karli and Tung lakes and the possible natural path of overflowing lake water (blue line). The white arrow indicates the planned 450-m-long artificial spillway, which was constructed in the first half of 2006. The smaller Tung Lake has also an artificially controlled overflow; Karli Lake level has reached the constructed spillway in April 2007 


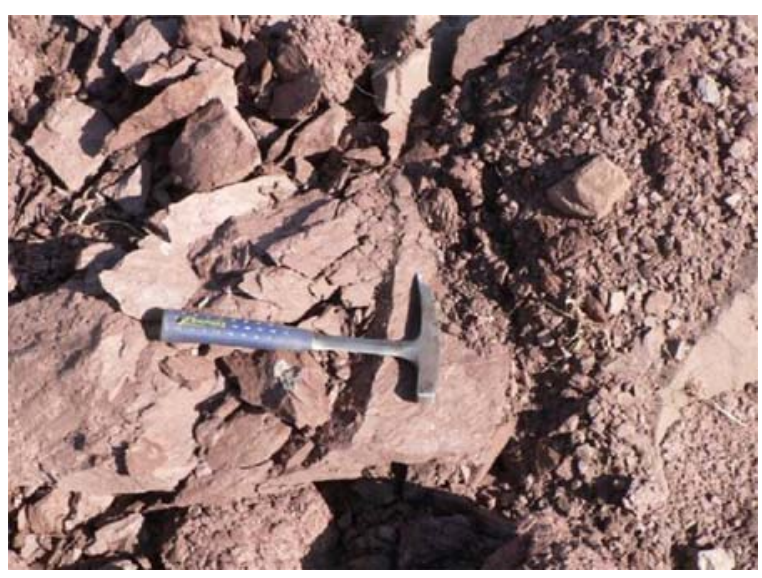

Fig. 5 Shale of the Murree Formation on dam proximal to the landslide (hammer for scale). The clayey to silty material is crumbling apart, wetted by the morning dew. The resulting soil is quite impermeable and can thus act as an aquiclude. Monsoon rainfall will enhance this effect, adding to the consolidation of the slide debris

space and time. The historically documented earthquake of 1555 was assigned to this gap and could be responsible for the younger of the above-mentioned Holocene landslides; but further seismological and geological investigations are necessary to verify this hypothesis. The actual landslide of 2005 (Figs. 3 and 4) was triggered just north of the eastern extension of the activated Jhelum or Tanda thrust fault, which strikes NW-SE and separates the Kamlial Formation from the Murree Formation (Early Miocene). The latter is composed of red sandstone, siltstone and claystone,

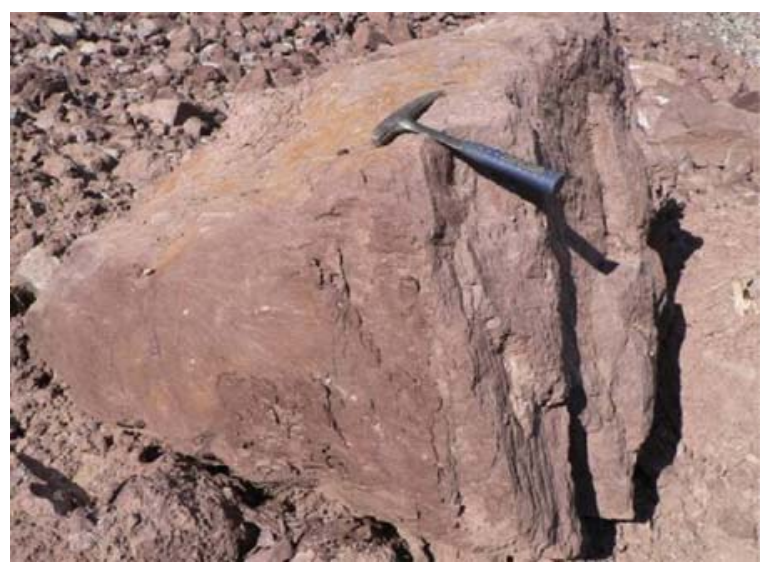

Fig. 6 Sandstone block of Murree Formation in the distal highest part of slide mass (elevation $1446 \mathrm{~m}$, hammer for scale). The size and number of large blocks increases with increasing distance from slide (segregation). While excavating the artificial spillway in the proximal area, only a few large blocks have been found and it was in this formation that the present landslide occurred on Dana Hill (Figs. 5 and 6).

The escarpments as well as the V- to U-shaped elongated sliding trough again have a tectonic origin, dominated by a NNE-plunging syncline with, in parts, tightly folded anticlines and other structural complications. Furthermore, both the top and the eastern side of Dana Hill are completely shattered, laterally spread and crisscrossed by cracks, slumps and slides, with the cracks striking mostly perpendicular to the synclines and anticlines, i.e. NNW-SSE (Fig. 7). At the south-facing escarpment of the slide, on the western crest of Dana Hill, there is still a large amount of destabilized rock material lying or hanging in critical condition, possibly allowing further rockslides (Fig. 8).

The landslide has an overall volume reaching probably 65 Mio $\mathrm{m}^{3}$. The affected area covers a total of $1.81 \mathrm{~km}^{2}$; the debris dam spreads out across $0.89 \mathrm{~km}^{2}$. The maximum height difference amounts to $940 \mathrm{~m}$, with the highest point at the crest being at $2038 \mathrm{~m}$ a.s.l. The composite rock avalanche occurred in three surges within half a minute (according to eyewitnesses), ran up on the other side of the valley and overrode the crest separating Karli from Tung Valley to reach the lowest point of its course just north of the former confluence of Tung and Karli Streams. To assign an average thickness to the complex slide would overtly simplify the sliding mechanism; in fact, it is not clear how much of the

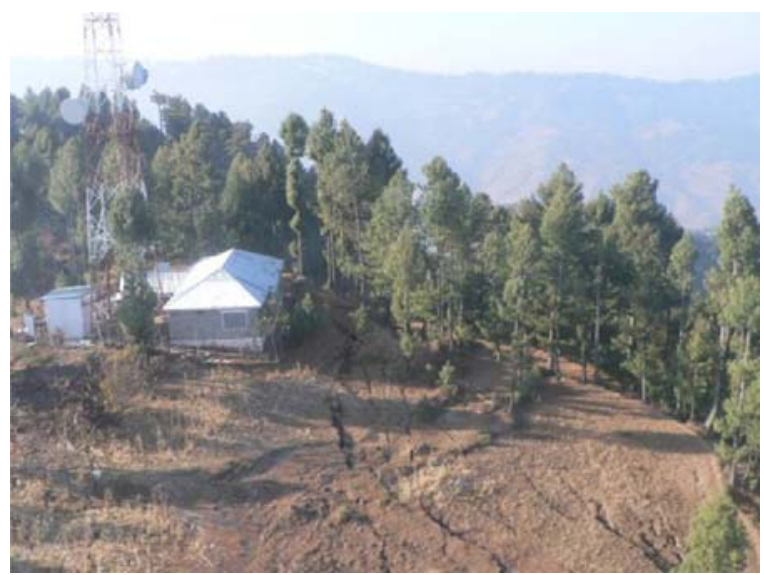

Fig. 7 Lateral spreading at Dana hilltop in the vicinity of the SCO-Tower. Most cracks are oriented N - S. Such cracks can be seen all along the Dana hillcrest from the Tanda fault in the south to Dana hilltop (Heli view to south) 


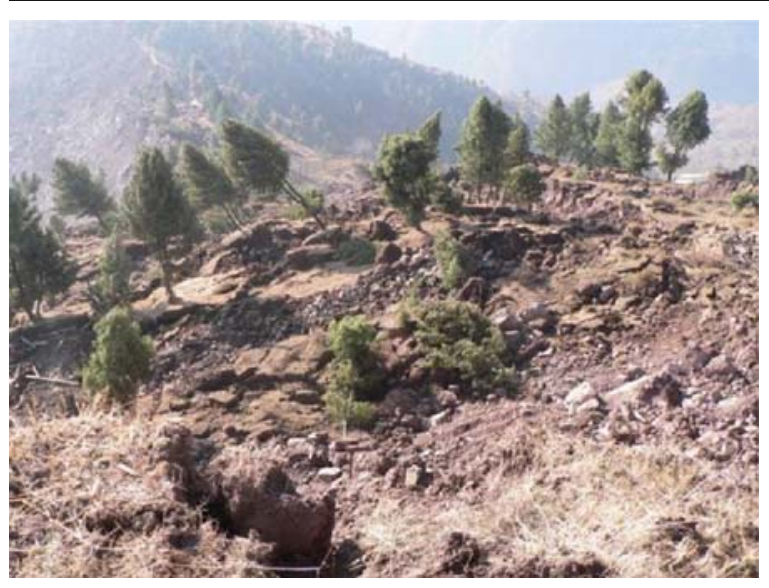

Fig. 8 Massive disruption of the Murree formation at the hillcrest between the communication tower and the top of actual landslide (view to south). This scene looks quite different from a normal landslide escarpment. Large amounts of shattered rock remain on the slope in unstable condition, which could potentially create further mass movements

older (historic, 1555?) debris is buried beneath the present landslide mass.

The settled slide mass can be divided in three distinct lobes. A saddle forming the possible natural overflow in situated at 1,369 $\mathrm{m}$ a.s.1. in the proximal area near the northern base of the slide mass; south and east of this point the bulging debris dam rises to a maximum of 1,446 $\mathrm{m}$ a.s.1. The main dam in the proximal valley created the larger Karli Lake, with a possible natural maximum volume around $61.7 \mathrm{Mio}^{3}$, and a secondary dam in the more distant creek of the Tung River created a smaller lake (Tung Lake), the natural maximum volume of which is estimated to be ca. 3.6 Mio $\mathrm{m}^{3}$. The highest point of the main dam, thereby, is situated ca. $77 \mathrm{~m}$ above the saddle, where the natural overflow would happen first. There, the total debris thickness adds up to no less than $350 \mathrm{~m}$. In this distal (downstream) part, the dam mainly consists of large sandstone blocks (according to surface observation). There, a valley-like trough has been formed since the earthquake. The author has observed similar phenomena on large landslides in Pamir (Schneider 2004). The proximal and lower part of the dam is composed of sandstone fragments in a dominant matrix of disintegrated siltstone and claystone. Secondary slumps have formed on the northern side of the slide as well as on the northern part of the dam.

All figures shown here are obtained from the collaboration with the local surveyors and geographic information system (GIS) specialists from NESPAK, SUPARCO and Frontiers Work Organization FWO; some of them are in contradiction to Dunning et al. 2007.

\section{Work carried out}

The author was assigned in October/November 2005 to January 2006 as the geological expert to the "Joint UNEP/OCHA Environment Unit" situated in Islamabad and at the UN camp in Muzaffarabad, reporting daily to the Pakistan Army and the authorities. His responsibilities included the safety against rock fall and landslides of the transport routes that had been damaged by the earthquake. The UN Humanitarian Information Centre for Pakistan (UN-HIC) provided the required geographical information. Remote sensing information from UNOSAT first identified the Hattian landslide. As a consequence, after a helicopter reconnaissance with a touchdown at Dana Hilltop (Fig. 7) and on the landslide dam, a first assessment of the situation was carried out by the author early November 2005. The following investigations were then initiated with the Pakistan Army Corps of Engineers and the Geological Survey of Pakistan as well as local authorities:

- A topographical survey of the slide and catchment area was undertaken, including a rough survey of the downstream area as far as Hattian Village in the Jhelum Valley;

- A detailed geological survey of the area was completed, with special emphasis on cracks and mass movements, as well as loose scree and soil downstream to Hattian;

- Surface sampling was undertaken to determine the geotechnical properties of the slide mass using laboratory analyses;

- A regime of daily observations of the water level in the two-pond lakes was initiated; an overflow of the Karli Dam was expected to begin after the Monsoon rain;

- Hydrological, hydrogeological and meteorological surveys were undertaken of the catchments, as well as the observation of springs below and possible seepage through the dam;

- Observations and measurements of possible movements on cracks and sliding planes were initiated, together with observations to detect dam instability; 
- Modeling of possible flood waves was initiated, whether induced by seepage failure, back erosion of the dam or slides into Karli Lake. This included modeling of possible debris flows downstream.

The geological work was carried out by the Geological Survey of Pakistan; the engineering work packages were planned by the Pakistan Army Corps of Engineers and National Engineering Services Pakistan (NESPAK); the excavation and construction work was undertaken by the Frontier Works Organization (FWO) construction company. Further remote sensing and modeling work is under way at the Institute for Applied Geology IAG-BOKU Vienna and the Geographical Institute at Zurich University in the form of a Master's thesis.

During January 2006, an international conference on the effects of the earthquake was organized by the Government of Pakistan in Islamabad (Kausar et al. 2006), where the author reported (Schneider 2006b), as well as Nakata and Kumahara (2006), Tapponnier et al. (2006) and others. A briefing as well as a reassessment of the situation and the work already done was carried out with the Pakistan Army Corps of Engineers and the Geological Survey of Pakistan, in coordination with relevant third parties. In conclusion, the necessary next steps were determined in accordance with the development and future needs.

Later missions of third parties studied the stability of the debris mass, the effects of flood waves and over flowing, as well as restoration and reconstruction measures (JSCE 2006; Harp and Crone 2006; Dunning et al. 2007).

\section{Discussion}

The following lake outburst scenarios were considered:

- Failure of the dam by seepage/piping/suffusion;

- Backward erosion of the dam caused by overflow over the lowest part of the dam crest;

- A slump or slide from the SE slope of Dana Hill into Karli Lake;

- A flood wave overtopping the dam caused by a slump or rockslide;

- Partial erosion or a dam breach caused by an overtopping flood wave.

The hazards created by the smaller Tung Lake were considered much less serious than those created by the larger Karli Lake, but had to be considered still.

The following mitigation measures were proposed to the government by the author to lower the risk of a possible outburst flood. Most of them have been subsequently implemented:

- As a first measure, helipads as well as a $4 \mathrm{~km}$ access road from Hattian to the dam sites needed to be built for transport of heavy equipment.

- Excavation of a spillway, $130 \mathrm{~m}$ long, to lower the water table at Tung Lake, a comparatively easy task, which was begun as soon as the road reached this dam.

- Overflow by Karli Lake of the natural saddle (1369 $\mathrm{m}$ a.s.1.) at the foot of the affected slope needed to be avoided, not least because backward erosion of the dam by an overflow was thought to be very likely. So a second spillway, $425 \mathrm{~m}$ long, was constructed in the period up to June 2006 to keep the water table low at impounding Karli Lake and to reduce back erosion in case of an overflow. Since an excavation (undercutting) at the foot of the slide could have interfered with the stability of the slope, a deeper channel with reinforcement by gabions and riprap was planned in the central part of the dam rather than in the lower-lying saddle (Fig. 4). Possible seepage or piping was monitored closely, as the hazard of inner erosion (suffusion) is given especially during the first phase of consolidation. Drill holes with piezometers were planned to observe the rising and progressing pore water front.

- Hazard maps as well as preliminary evacuation plans of vulnerable areas, dwellings and infrastructure in the upstream and downstream areas prone to flooding had to be compiled. Appropriate measures needed to be taken, and the most hazardous areas were evacuated.

- A meteorological station was planned at the SCO-Station at Dana hilltop, as well as hydrological stations and observation of further mass movements.

All these mitigation measures needed to be enforced during the first quarter of 2006, before the big snowmelt and summer monsoon. Heavy precipitation and the associated first highs of water level in the lakes and rising pore water pressures within the shattered rocks adjacent to the lakes were the most 
Fig. 9 Google Earth (C2007 Google, (C)2008 Digital Globe, (C2008 Europa Technologies, high resolution composite dated 10-03-2006, eye altitude $5.6 \mathrm{~km}$ ). Possible flood pathway from dam site at right (south) over $4 \mathrm{~km}$ downstream through narrow gorge to Hattian and Jhelum Valley at left. The smaller Tung lake, with its artificial spillway, is visible at middle right of scenery. The construction of the lower part of the $450 \mathrm{~m}$ long Karli Lake spillway on the slide mass is not visible to this date in the lower right corner of the composite

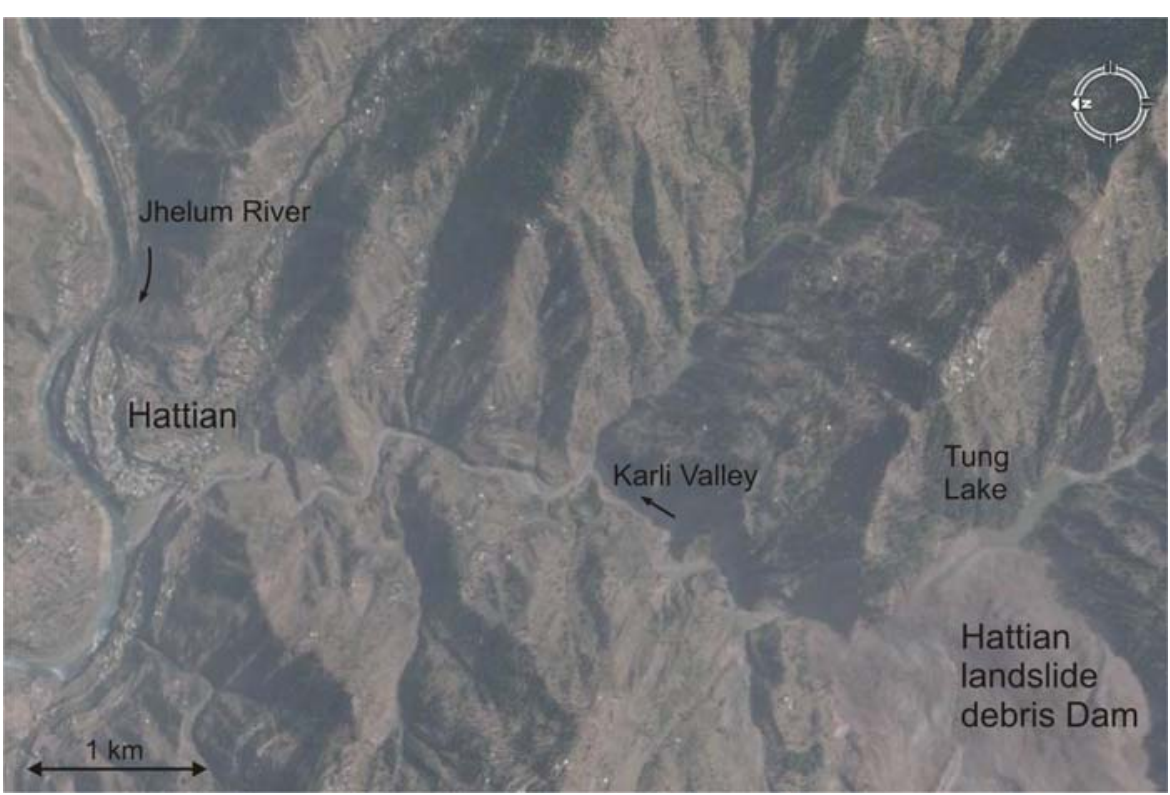

critical hazards with respect to a potential outburst flood. This could have led to a flood wave or debris flow rushing down Karli valley towards Hattian and the Jhelum valley.

Since the first rainy season was not as heavy as feared, the level of Karli Lake did not rise as fast as foreseen by the author and no major slides occurred into the lake. The water level of Karli Lake reached the excavated spillway end of March 2007, and in the first days of April, the water started to flow gently along the spillway. Dunning et al. (2007) describe seepage of water into the dam body in June 2007. Further development of dam stability in respect of water infiltration from the spillway needs to be observed closely. According to Dunning et al., the dug channel is only $10 \mathrm{~m}$ deep. According to NESPAK (personal communication) the spillway is performing well. Except for some minor seepage, no other seepage or distress has been reported on the landslide dam. Monitoring is in place with inflows and outflows being recorded. There have been no major secondary slides. The lake has now been handed over to the Government of Azad Jammu and Kashmir.

The author initiated a Master Thesis with the task of calculating the probability of dam breaching, and modeling of consecutive destructive flood waves reaching Hattian in Jhelum Valley (see Fig. 9). The results of this work will go beyond JSCE (2006) and are to be published later. In the author's opinion, the hazard of breaching of the dam is very unlikely now, since the stability of a natural dam increases by consolidation. Such natural landslide dams usually break within the first few years, or other stabilise with time. The author has observed several examples of such dams of different size and age in the Pamir and Tian Shan in Central Asia (Schneider 2004). There are excellent examples of breached and intact dams.

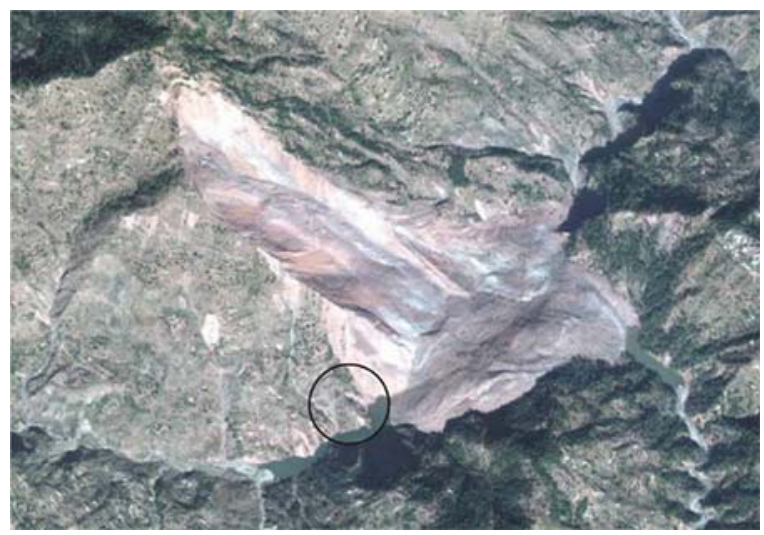

Fig. 10 Oblique true colour scenery of Hattian slide and lake formation area (C2005 DigitalGlobe, QuickBird II, 27-102005). Note the complex geometry of the slide with its central bulge, lower part of it interpreted by the author as an older mass. The debris dam shows ridges and scars. The Karli and Tung lakes are observed to have started to fill up. Clearly visible is the narrow gorge downstream of the landslide dam. The SE facing slope of Dana Hill (left side of the image) shows recent landslide scars. The Tanda Fault is just outside the image on the left side; the hazardous slide developing on the left side of the lake shore is encircled and shown in detail in Fig. 11 
Fig. 11 Helicopter view (Nov. 2005) of the active slide or slump on the lower flank of Dana Hill, west or orographic left side of Karli Lake. In the mean time, the lake level rose up to the destroyed houses on the sliding mass. Note the bulging and cracking of the slope south of the active slide. The unstable foot of this slope is submerged. Possible consequences of these mass movements are discussed in the text above

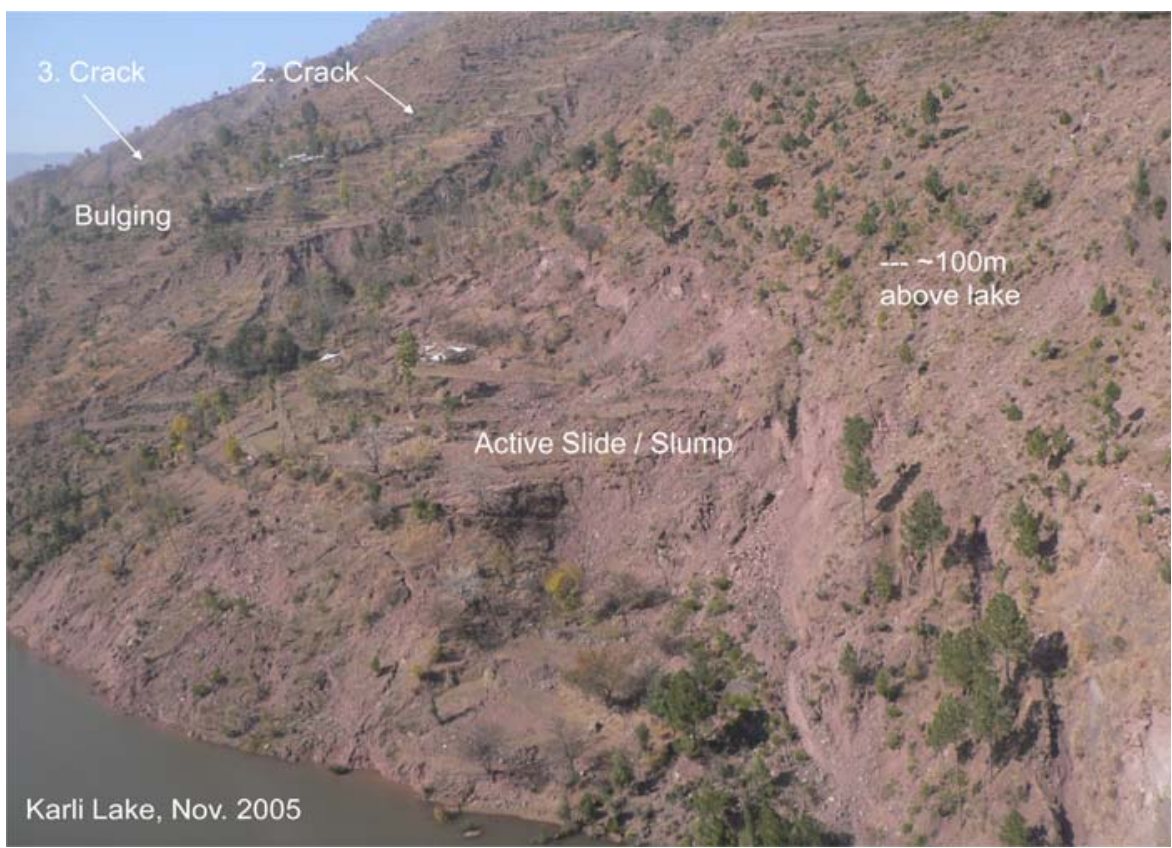

a

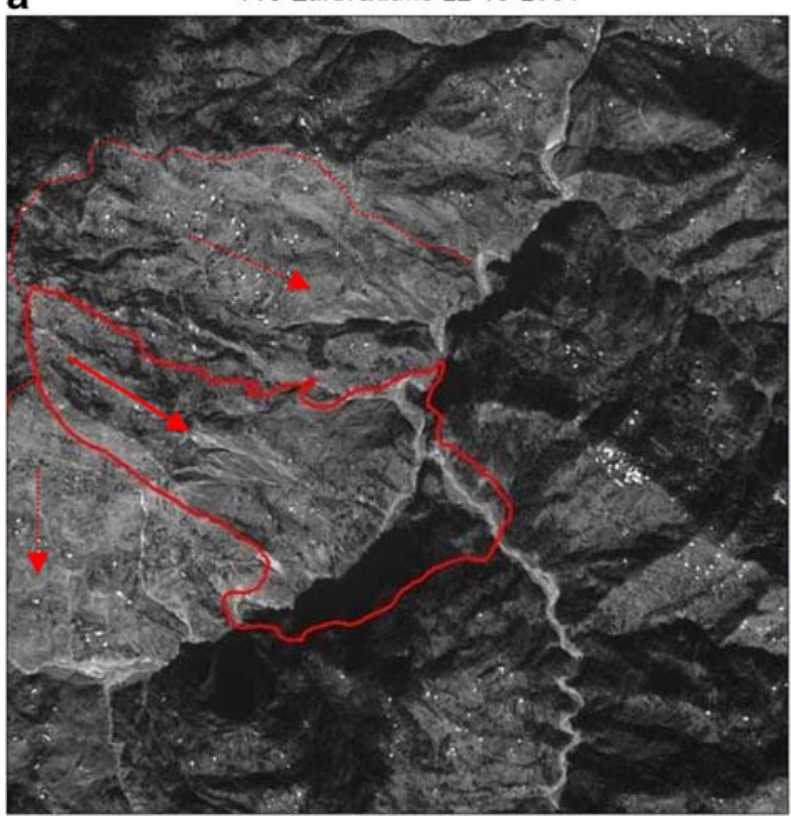

Fig. 12 a, b: Satellite images of Hattian slide area (SPOT 4, XI and panchromatic M-modus, sceneries by SUPARCO, Pakistan, 2005, modified by the author) before the slide (22-10-2004, left), as well as after the earthquake triggered slide (21-102005 , right), also showing the early stage of the formation of Karli and Tung Lakes. Karli Stream flows north (towards the b

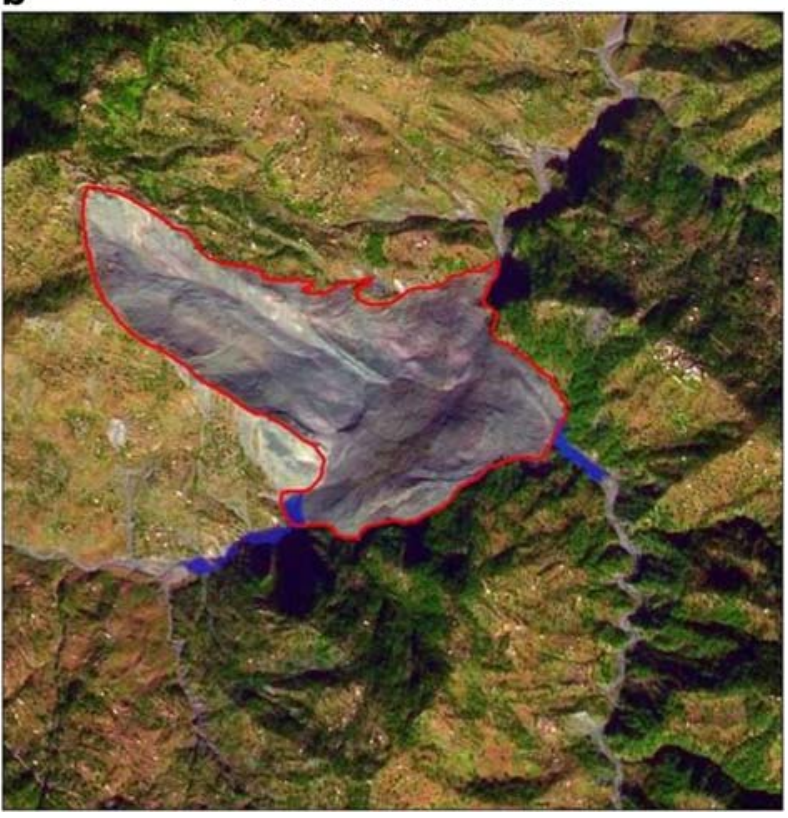

top of the image). Note on the left image the escarpment and sliding mass of the earlier (historical?) landslide at approximately the same location as the actual one (solid arrow). Two even older, possibly Holocene landslide scars (dashed lines and arrows) were detected during field reconnaissance and are recognizable just north and south of the actual event 


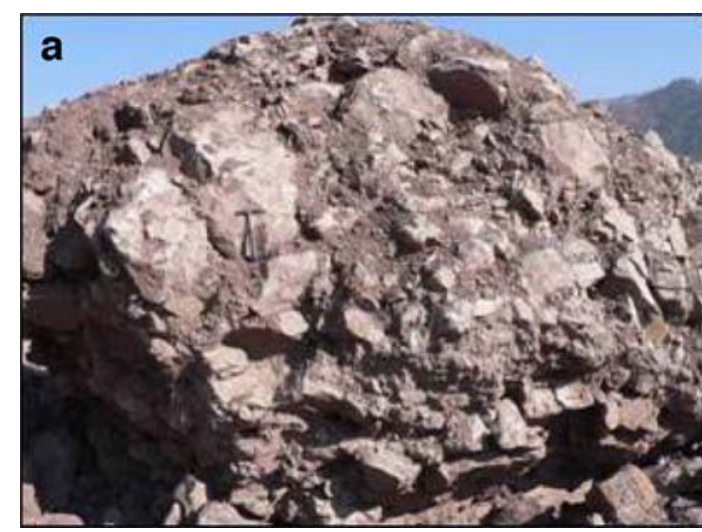

Fig. 13 a, b: Cemented breccia of slide debris from former landslide found in central distal area of landslide dam on the left photo. The cement consists of carbonates (tested with hydrochloric acid, see hammer for scale). The right photo

Also, even a flood wave created by a future slide into Karli Lake will do ever less damage with time, since the dam surface will be less vulnerable, once it has consolidated and been covered by vegetation, with the exception of the spillway, as mentioned above.

In Figs. 10 and 11, an active slide or slump is visible, developing on the left shore of the growing lake. This mass movement could trigger a flood wave, if a sudden failure would occur. A rapid lowering of the lake level caused by a partial dam failure was faired during the early stages of natural overflow of the dam. This would have caused an overpressure of the interstitial water in the slope triggering the slump. This hazard was minimized by human interaction and by time.

During the consultancy, satellite images from before and after the event using the CORONA, LANDSAT, TERRA ASTER and SPOT platforms were collected. They show an older (possibly historic) sliding mass at the location of the new landslide, which was overrun by the actual slide (Figs. 2, 3 and 12). The bulging mass in the centre of the actual slide seems to consist in the lower part to a large extent of older slide material (Figs. 3 and 4). Some boulders on the actual dam deposit are clearly cemented former slide breccias as shown on Fig. 13a, in comparison to the actual slide debris shown on Fig. 13b. At the valley bottom, the Karli stream incised deep into the former landslide mass. On the CORONA stereo pair (Fig. 14), the massively eroded left (western) riverbank with slumps can be clearly recognized.

The hypothesis of a former, probably historic landslide at the location of the 2005 landslide, as

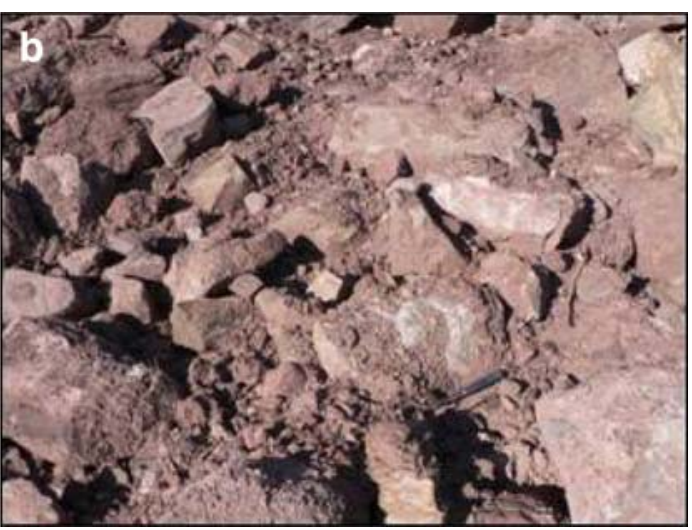

shows in comparison a similar breccia with sandstone components, clay and silt as matrix, but not cemented, lying in the central part of the actual landslide dam (see hammer for scale)

well as other landslides from Dana Hill, postulated by the author is in contradiction with the observations of Harp and Crone (2006), Dunning et al. (2007) and others. It is based on the morphology before and after the 2005 slide and on the observed cemented breccias. Further investigation will be done to test evidences for this hypothesis.

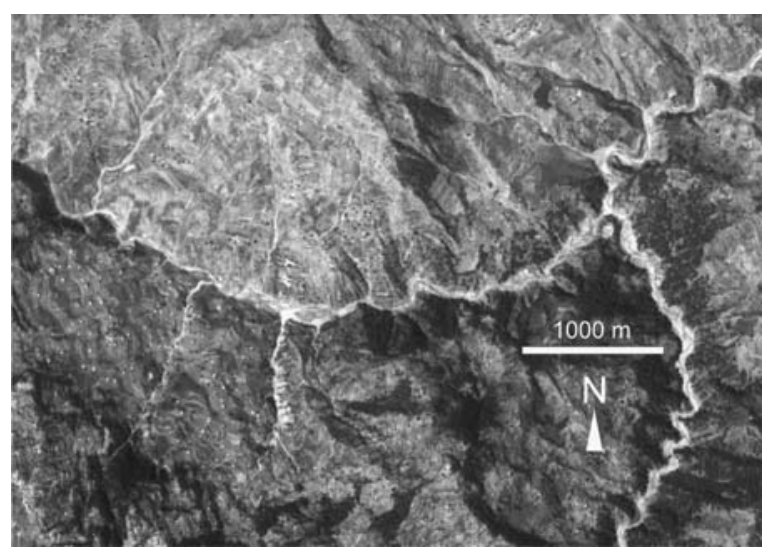

Fig. 14 Analogue CORONA photo (15-09-1971, courtesy of T. Nakata). Confluence of the Tung and the Karli streams (approx. 1,130 $\mathrm{m}$ a.s.1.) with the south facing former landslide (in the upper left of the photo), and the lower part of the "historic" landslide, showing the deeply incised streams and the eroded base of the slide (in the upper right of the photo, see Figs. 2 and 12a for orientation). Karli Stream is flowing from left to right. This view shows, when compared to Fig. 12, more details of the rugged surface and the deeply incised stream bed, with which the actual landslide interfered. Here, in 1971 (and also 2004, Fig. 12), no major village is visible, suggesting an exaggeration of the death toll (up to 1000 casualties) in Dandbeh hamlet caused by the slide 


\section{Conclusions and recommendations}

The investigations and experience gathered during the mitigation works at Dana Hill and Karli Valley, in the vicinity of the Hattian landslide, lead one to conclude that this area has been very hazardous even before the devastating earthquake of 2005. Similar hazards exist on most south sloping flanks along the north dipping Tana thrust fault. In Kashmir, most of the larger mass movements were directed towards SE to SW; many of them were reactivated older slides. Huge masses of shattered rock still remain in hazardous positions above the populated valleys in a treacherous equilibrium. These masses can be destabilized quite easily by heavy precipitation or snowmelt and/or earthquakes, and therefore have to be considered as firstorder, remote geohazards.

Falls, slides or rapid flows are a substantial problem after an earthquake, threatening the vulnerable population and infrastructure in the lower parts of the valleys, especially if flood waves are created. This was clearly the case in Karli Valley above Hattian. The mitigation work done there is very valuable, but there is still a certain amount of remaining risk, particularly towards the end of the wet seasons. Detailed investigations and monitoring must continue and evacuation/rescue plans must be thoroughly maintained.

In general, a careful interpretation of seismotectonics, geology and morphology, taking the past as well as the ongoing processes into consideration, should result in risk evaluation and geohazard zone maps. The role of former landslides and slide debris, prone to be reactivated by earthquakes, but also by exceptional precipitation, ought to attract more attention during hazard zone mapping.

Unfortunately, it is only after a catastrophic event that mitigation works are common practice. To minimize the risk of the population's being affected by future events of such a nature in seismically active mountain regions, the scientific community, stakeholders and politicians are well advised to work together. Knowing the hazards, risk awareness and preparedness on all levels helps to save lives and, in the long run, financial resources also.

Acknowledgements The author was a member of the UNOCHA and UNEP/UNDP joint relief task force in October/ November 2005 in Islamabad and Muzaffarabad after the 8th
October Pakistan earthquake. This assessment was only possible with the full support of the Swiss Agency for Development and Cooperation SDC, the Joint UNEP/OCHA Environment Unit and UN-HIC Office in collaboration with the Pakistan Prime Ministry Office, the Military and Government Agencies, which also released unpublished data and documents. A large amount of further information used was available during emergency time at the intra/internet and interpreted by the author (e.g. UN-OCHA ReliefWeb, Virtual OSOCC and UNOSAT). Many links are not accessible any more, the origin not possible to quote. The links presented in the references were tested in January 2008.

The author would like to thank the Pakistan Army and the Geological Survey of Pakistan for their excellent cooperation, and also Prof. Harsh Gupta of the Indian National Geophysical Research Institute (NGRI) for the invitation to contribute to the special issue on the 2005 Muzaffarabad earthquake. The author also greatly acknowledges the thorough work of the reviewers, especially Wolfgang Straka. Special thanks also to our technical assistant for drawings 1 and 2. Furthermore, the financial support of the SDC for the travel expenses of the author to the Earthquake Conference in Islamabad in January 2006 is gratefully acknowledged.

\section{References}

Aydan Ö (2006) Geological and seismological aspects of Kashmir earthquake of October 8, 2005 and a geotechnical evaluation of induced failures of natural and cut slopes. Journal of School of Marine Science and Technology, Tokai University 4(1):25-44

Dunning SA, Mitchell WA, Rosser NJ, Petley DN (2007) The Hattian Bala rock avalanche and associated landslides triggered by the Kashmir Earthquake of 8th October 2005. Eng Geol 93(3-4):130-144

EMSC, European-Mediterranean Seismological Center (2005) Earthquake Mw 7.6 in Pakistan October 8th, 2005. http:// www.emsc-csem.org/

GSP-Geological Survey of Pakistan (2005) Tectonics, geology and seismicity of epicentral area. http://www.gsp.gov.pk/

Harp EL, Crone J (2006) Landslides triggered by the October 8, 2005, Pakistan Earthquake and associated Landslidedammed Reservoirs. USGS Open-File report 2006-1052. http://pubs.usgs.gov/of/2006/1052/pdf/ofr-2006-1052.pdf

Harvard (2005) Magnitude 7.6 PAKISTAN, Saturday, October 08, 2005 at 03:50:40 UTC. http://www.seismology. harvard.edu/

JSCE (2006) Quick Report of the JSCE Mission for Geotechnical Survey along Jehlum and Kunhar Valleys (Ver. 1.1) http:// www.jsce-int.org/Report/disaster_information.htm

Kausar AB, Karim T, Khan T (eds) (2006) International Conference on 8 October 2005 Earthquake in Pakistan: Its Implications \& Hazard Mitigation, extended abstracts. Geological Survey of Pakistan, Islamabad http://www.gsp. gov.pk/international_conference.pdf

Mona Lisa, Kausar AB, Khwaja AA, Qasim Jan M (2006) October 8, 2005 Pakistan Earthquake: Preliminary observations and report of an international conference. Episodes 29(3):206-208 
Nakata T, Kumahara Y (2006) Active faults in Pakistan with reference to the active faults in the source area of the 2005 North Pakistan Earthquake. Extended abstract. In: Kausar $\mathrm{AB}$, Karim T, Khan T (eds) International Conference on 8 October 2005 Earthquake in Pakistan: Its Implications \& Hazard Mitigation, extended abstracts. Geological Survey of Pakistan, Islamabad http://www.gsp.gov.pk/international_ conference.pdf

Owen LA, Kamp U, Khattak GA, Harp EL, Keefer DK, Bauer MA (2006) Landslides triggered by the October 8, 2005, Kashmir Earthquake. In: Geophysical research abstracts, vol. 8

Sato HP, Hasegawa S, Fujiwara S, Tobita M, Koarai M, Une H, Iwahashi J (2007) Interpretation of landslide distribution triggered by the 2005 Northern Pakistan Earthquake using SPOT 5 imagery. Landslides, Volume 4, Number 2
Schneider JF (2004) Risk Assessment of Remote Geohazards in Central and Southern Pamir, GBAO, Tajikistan. NATO Advanced Research Workshop 'Security of natural and artificial rockslide dams' (Bishkek, Kyrgyzstan 2004)

Schneider JF (2006a) Mass movements in Northern Pakistan triggered by the October 2005 Earthquake. In: European Geosciences Union EGU (ed) Geophysical research abstracts, vol. 8, EGU, 2.-7.4.2006, Vienna

Schneider JF (2006b) Earthquake triggered mass movements in Northern Pakistan with special reference to Hattian landslide. Extended abstract. In: Kausar et al (2006)

Tapponnier P, King G, Bollinger L (2006) Active faulting and seismic hazard in the western Himalayan Syntaxis, Pakistan, Keynote address. In: Kausar et al. (2006)

USGS Global Seismographic Network (2005) Magnitude 7.6PAKISTAN 2005. October 8 03:50:40 UTC. http:// earthquake.usgs.gov/regional/neic/ 